Tomasz Opach

\title{
THE PROBLEM OF CARTOGRAPHIC REPRESENTATION IN RELATION TO THE POLISH CULTURAL LANDSCAPE
}

\begin{abstract}
The problem of representing the Polish cultural landscape consists of two components. The first component is the choice of content. Wishing to define the breadth of the content of a cultural landscape map, one needs to remember that it is composed of two facets. The first facet, the material result of human activity, is easily discernable in the field and easily illustrated on a map. Elements included in this facet are: sacred and secular historical structures, the spatial layout of cities, archeological sites etc. The second facet of cultural landscape needs to be considered in immaterial terms. It is difficult to illustrate on a map, because its elements do not lend themselves to being topographically situated. One could mention, for example, religions, customs and traditions, a common historical past etc. Most often, one can only indirectly speculate about this facet of the cultural landscape, on the basis of the material characteristics of the cultural landscape.

The second problem related to presenting cultural landscape on a map is the choice of graphic form for the map. The problem is to a large extent tied to difficulties stemming from the necessity of maintaining semantic correctness (the relation between "symbol" and "object"). In practice, during the graphic editing of a map representing the cultural landscape, one should remember to: a) choose a scale suitable for the representation, upon which depend the degree of detail and the generalization of the content; b) correctly depict the variation boundaries, taking into account sharp and fuzzy boundaries; c) make a well-designed symbol key.
\end{abstract}

Key words: landscape, cultural landscape, cultural heritage.

Cultural landscape constitutes the subject of interdisciplinary studies it is of interest to those studying various scientific disciplines, such as geography, ethnography, biology, landscape architecture and urban studies. Within each of the fields mentioned, research methods have been developed in which the map often serves as a basic research tool. While methodological problems are often discussed within each of the above-mentioned disciplines, the problems associated with using maps in research are often dismissed. The problems originating directly from the representation of cultural landscape on a map have never been the subject of scientific debate.

\section{CULTURAL LANDSCAPE}

The concept of cultural landscape could be considered as the combination of the meanings of three words: land (the region), scene (the features) and 
culture (the creations of humanity). The result is a definition by which cultural landscape is seen as the material and immaterial features of the creations of people inhabiting a given region. This is similar to the way in which landscape architects see this concept (Bogdanowski, 1976). In their view, the cultural landscape is a part of the general landscape, incorporating elements shaped by human activity. On the other hand, according to the definition accepted by biologists (Umiński, 1994), cultural landscape, as a set of elements of human activity, interacts with the environmental aspect of the landscape.

Two aspects of cultural landscape can be distinguished. The first is material. It is the visible result of human activity, and is composed of elements making up, for instance, the rural landscape (the type and layout of buildings; the layout, size and degree of agglomeration of farming fields) (Szulc, 1995), the urban landscape, or the industrial landscape (with its variety the mining landscape). Thanks to the material aspect, this facet of the cultural landscape can be represented on a map: first, by specifying the geographic coordinates of the individual objects and then by carrying them over onto a map.

The second aspect of cultural landscape needs to be considered in different terms. These are immaterial, spiritual terms. The spiritual aspect of cultural landscape contains elements such as: religion, tradition, a common historical past, etc. This facet is difficult to represent on a map.

Although the cultural landscape comes into existence by human transformation of the initial natural landscape, there exists a clear difference between the study and representation of the natural landscape and the study and representation of the cultural landscape. In the natural sciences, we study and analyze what already physically exists, meaning we study the characteristics of objects and phenomena, which exist not due to human creation, but because that is their actual nature (F. Znaniecki, 1973). This situation is different in the case of the cultural landscape and its material aspect in particular, for it is often the case that the characteristics of objects and phenomena studied exist only because they "belong to someone," or, in other words, they exist in the activities and experiences of certain people (Znaniecki, 1973).

In the case of the immaterial aspect of cultural landscape, defining the breadth of this concept and relating it to the meaning of the term cultural heritage poses a significant problem. The author sees cultural heritage as the most valuable aspects of the whole of creative human activity (architectural structures, Polish language artifacts, folk songs, etc.). Cultural landscape on the other hand has a more restricted meaning, because it encompasses only those objects and phenomena which have an indirect or direct "visible" effect (e.g. the visible effect of the Eastern Orthodox denomination of Christianity is the unique look of the place of worship, manifested by the characteristic architectural and interior decoration details of an Eastern Orthodox church.) 


\section{THE PROBLEM OF CONTENT}

The content of a map is a function of its scale and purpose. One should therefore reflect upon what information should be found on a map representing a cultural landscape. An editor faced with the task of representing cultural landscape objects and phenomena on a map must first specify the landscape's elements.

Sacred and secular historical structures - historical monuments of the greatest value - are without a doubt the most important element of the material aspect of a cultural landscape. In the case of representing sacred historical structures on a map, it is important to render details such as:

- by which religious group and denomination the given structure was used;

- when it was built and its architectural style;

- the material from which it is built (wood, stone or brick).

Aside from the large historic architectural monuments, the other sacred historical objects which should also be mentioned are shrines and crosses, which are a constant element of the Polish cultural landscape.

Secular structures are in the second category of historical objects, which includes:

— structures - dwellings (e.g. palaces, courts, tenement-houses, villas);

- state institution and administration structures, cultural structures (e.g. town halls, theaters, schools, postal stations);

- defensive structures (e.g. castles, fortresses, towers, city walls);

- manufacturing and technology structures (e.g. workshops, mines, bridges, water mills).

Area complexes have a special place in the category of historical structures. In the case of a complex, aside from taking into consideration its individual components, it is important to render on the map the characteristics of it as a whole. The components of complexes are mainly parks and alleys, estate parks, cemeteries, Calvary shrines, defensive structures and granges.

An important element of cultural landscape is the special layout of cities (prior to, at, and following incorporation) and villages (the layout of buildings and roads, tracts of land). While presenting the characteristics of a network of settlements, one must not forget to provide information regarding the first historical record concerning the settlement, the charter law applied at the time of its incorporation (Polish, Ruthenian, German or Volhynian) and about who it belonged to (the church, royalty, nobility or another holder).

Cultural landscape is composed of a collection of archeological sites. In particular, this concerns structures which can be observed in the field - the remnants of fortifications, barrows, burial grounds with stone rings, as well as of cult centers. Their significance in the Polish cultural landscape is undeniable. 
The situation in which alongside the material aspect of the cultural landscape we wish to present its immaterial aspect warrants additional explanation. One should ask whether the map can include the spiritual elements of the landscape, which cannot be topographically localized. One can indirectly speculate about the spiritual aspect on the basis of the material characteristics of the cultural landscape (the indirect visible effect).

While we will have no problem in pointing out the elements of the material cultural landscape, pointing out the elements of the immaterial cultural landscape does pose certain problems. It is certain that both in case of the first and second aspect of cultural landscape, it is possible to point out the dominating, meaning the most important elements of the landscape that constitute its framework or fabric. These main landscape elements represent the most valuable part of the cultural environment and presenting them accurately on the map should be seen as the main goal.

Pointing out all the elements of the spiritual aspect of cultural landscape is difficult. This is due to the interdisciplinary nature of this concept as well as to the impossibility of pointing out all of the immaterial features which have an indirect material effect. However, in general one should make mention of:

- religious and denominational groups, folk beliefs,

- geographical and historical names,

- important historical events,

- traditions and the folk art associated with them,

- traditions and customs of ethnic minorities and their effect upon the material culture.

Another matter concerning the maps representing cultural landscape is the way their content is structured. Structuring may be done according to an analytic or synthetic approach (Fischer, 1933). Usually, we begin our research by looking at the analytic map, which is then used in the making of the synthetic maps, showing for example the extent of certain types of regions or the differentiation of regions.

The main aim of the analytic approach is the inventorying of study results. The basic trait of the inventorial map is the full characterization of the given phenomenon. Instead of using oral sources such as informants, regional monographs and records, the user has access to the cartographic representation, which provides information enriched by the notion of place. As a result, we gain insight into the spatial differentiation of the area.

An inventory in the form of a map has one other advantage. With the help of a code made up of previously agreed-upon symbols, the map allows us to interpret the information beyond the elementary level, what is not possible when using descriptions and tables. An elementary reading does not provide the opportunity for the discovery of relationships characteristic of groupings (Bertin, 1970), which we know as the basis for grasping the spatial differentiation and specificity of the given areas.

An example of the analytic approach is the Archeological Picture of Poland (Archeologiczne Zdjecie Polski - AZP). AZP is a research project which 


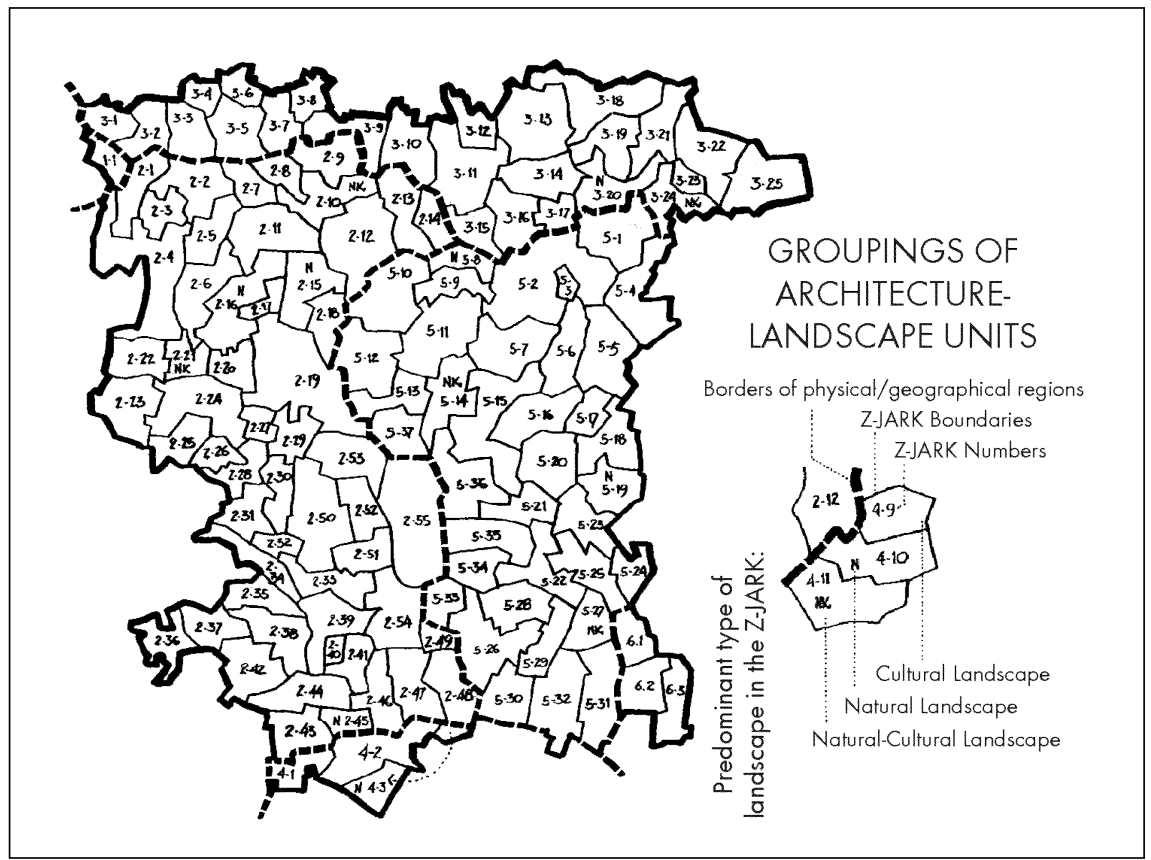

Fig. 1. Division of the Łódź Voivodship (administrative division before 1999) into groupings of architecture-landscape units (JARK).

entails the detailed investigation of the entire surface area of Poland with regard to the occurrence of surface archeological findings, according to a uniform system (Ławecka, 2000). The surface area of Poland has been divided into rectangular sections, $7.5 \mathrm{~km}$-long by $5 \mathrm{~km}$-wide, with each of these sections drawn up on a map having a scale of 1:25000. The sites documented in the field were all carried over onto the maps and described in appropriate site registers attached to the maps. Towards the end of 1998, it was estimated that $70 \%$ of the project had been completed.

Following the making of the cultural landscape element inventory, the next step is to work out the synthetic approach. This is most often done by first valorizing the cultural landscape and then developing a system for typology and regionalization.

Maps of regions and types are created by filtering the information contained on the analytic map. What part of the information taken from the analytic map will be used during the creation of the synthetic map depends upon the type of synthesis and the purpose for which the map is to be used.

An example of the synthetic approach is the set of cultural landscape conservation maps showing protected areas, created in accordance with the instructions of J. Bogdanowski (1994). They illustrate the effect of Z-JARK delimitation (short for zespoty jednostek architektoniczno-krajobrazowych groupings of architecture-landscape units) (Fig. 1) and of assigning to each 
of the given units the status of a historical, mixed or modern-day area. The character of the appearance and surface features of the area, as well as the important characteristics of each of the lands - historical and traditional divisions along with the chronological descriptions of settlement patterns were used for determining the status of the unit (Dylik, 1948).

\section{THE PROBLEM OF FORM}

Second after the choice of content is the question of what graphic form the map shall take. Cultural landscape objects and phenomena have to be translated into the graphic language of the map, in accordance with its rules of grammar.

Presenting the cultural landscape on a map is to a large extent tied to problems stemming from the necessity of being aware of semantic correctness (the relation between "symbol" and "object"). Semantic correctness is defined by the three rules of isomorphism (Ratajski, 1989) (Fig. 2).

- the isomorphism of place (the positioning of an object on a map must correspond to its positioning in reality)

- the isomorphism of form (the symbols on the map are a reflection of actual features)

- the isomorphism of content (the purpose of the map should be to convey the associations and disparities between the presented facts).

The creation of an effective cartographic medium is grounded in the awareness of the rules of isomorphism. The proper reading and correct interpretation of a map are required for making accurate inferences, and by the same token, for the map to be effective.
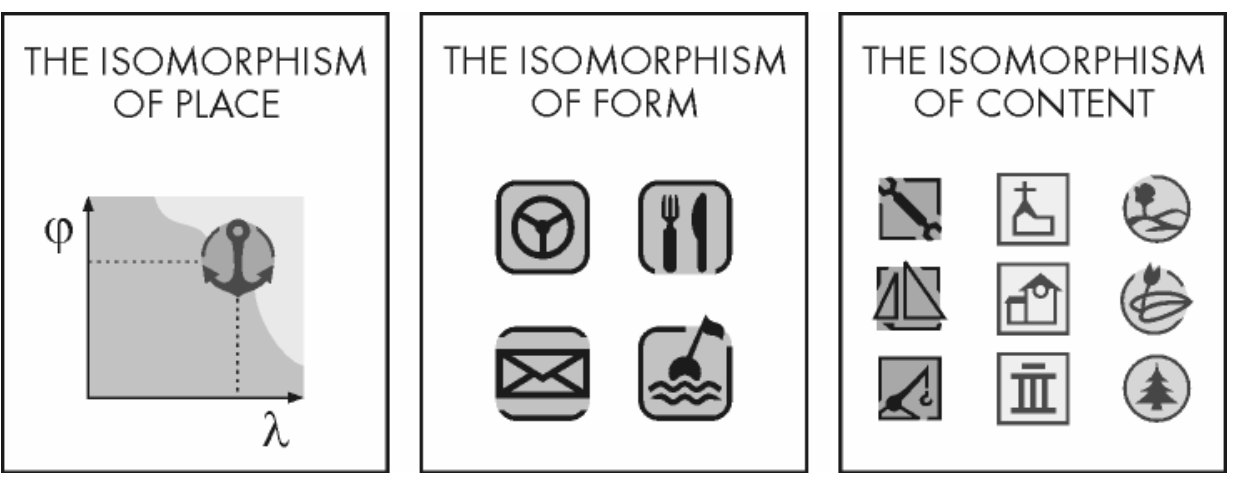

Fig. 2. Isomorphic correspondences on a map.

The most common challenges in the practice of cartography, related to the representation of cultural landscape on a map, are:

— choosing a scale suitable for the representation, 
- depicting the variations and their boundaries,

- designing a key of symbols.

The choice of scale for the map is one of the most important questions relating to the depiction of cultural landscape. The map scale has an effect upon the act of generalization about the phenomenon presented, as well as in part upon the method of cartographic representation which is to be used. For example, the same concept could be presented as a descriptive range with fuzzy borders (small-scale), a linear range with sharp borders (mediumscale), or by using symbols representing the topographic incidence of the phenomena (large-scale) (Fig. 3).
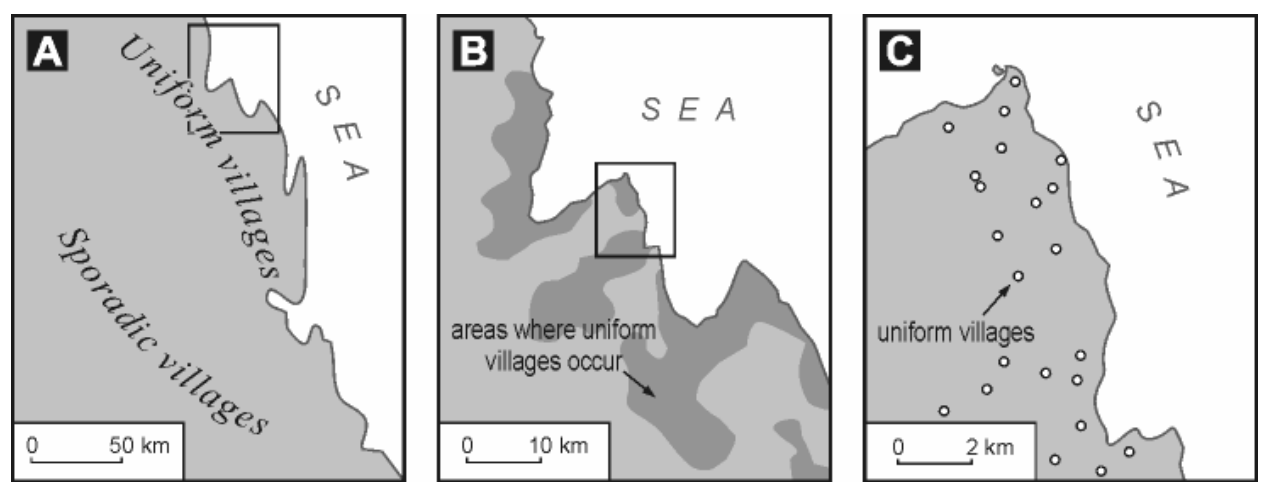

Fig. 3. The method of cartographic representation used depends on the scale of the map.

Inadequate knowledge or the uncompleted state of an investigation often make the creation of a large-scale map impossible. In such cases, some concepts can only be presented in survey and small scales. Maps illustrating important historical events as an element of the cultural landscape can be used as an example here. Often, it is possible for them to illustrate only the approximate spatial characteristics of phenomena.

On cultural landscape maps, the characteristics of objects and phenomena are usually presented at a nominal level. Information is carried over onto the map in the form of ranges (surface referencing) or symbols (linear and point referencing). The sharpness of the boundaries of differentiated regions presented on a cultural landscape map depends upon the traits of the phenomenon illustrated, the nature of the data, and the scale.

A trait characteristic of cultural landscape is the fluidity of the borders between its elements and the lack of clear and sharp divisions. For this reason, when creating a cultural landscape map, we often need to depict the attributes of the "mixed zones" (Smoleński, 1934). This we can do by drawing fuzzy borders (Fig. 4). This mainly concerns the elements of the immaterial aspect of cultural landscape, which are shaped in the human mind. We often have at our disposal materials which make the clear representation of the limitations of the occurrence impossible. In such cases we are 

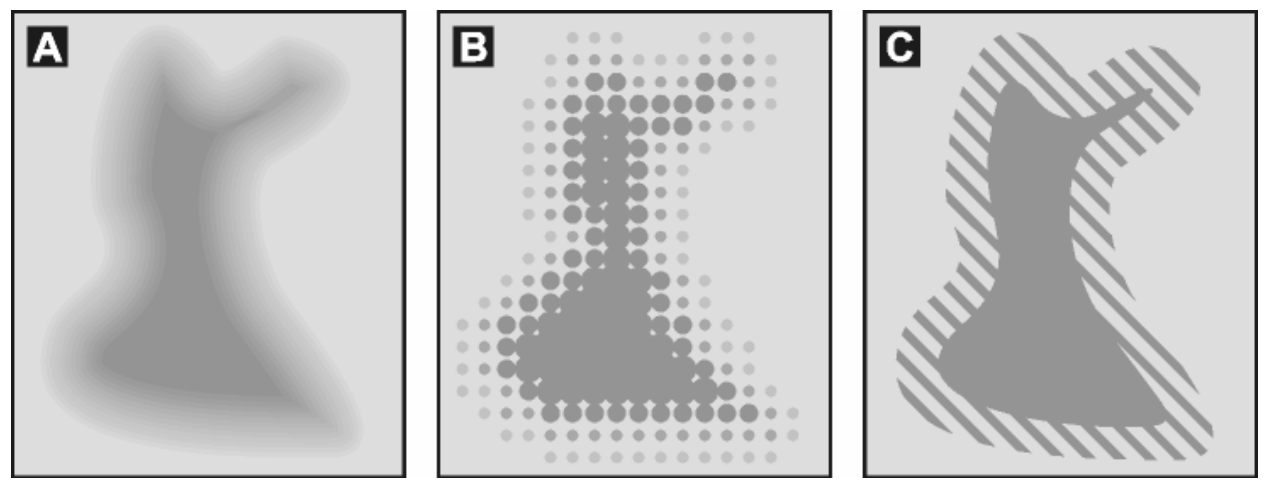

Fig. 4. The various ways of representing mixed zones.

unable to denote sharp boundaries for the objects and phenomena. The boundaries drawn must be fuzzy, what is related to our reservations concerning the regions for which we do not have data (Piskozub, 1987).

Most often, the fuzziness changes along with the scale of the map - respectively, it increases or decreases as the scale increases or decreases. The same phenomenon will have slightly different boundaries on a large-scale than on a small-scale map. The boundaries will be fuzzy in the first case and sharp in the second. The problem of border fuzziness mainly concerns synthetic maps, the maps of types and regions in particular.

In the creation of maps representing the elements of cultural landscape, a common problem is the design of the key of symbols. In the case of the analytic approach, we often need to present a number of characteristics relating to one object. For this purpose, we need to design a table legend (archeology, sacral monuments) (Fig. 5).

\begin{tabular}{|c|c|c|c|c|c|c|c|c|}
\hline & $\begin{array}{l}\text { Paleolithic } \\
\& \text { Mesolithic } \\
\text { to } 5500 \mathrm{BC}\end{array}$ & $\begin{array}{c}\text { Neolithic } \\
5500-2000 B C \\
\end{array}$ & $\begin{array}{c}\text { Bronze Age } \\
2000-700 B C \\
\end{array}$ & $\begin{array}{c}\text { Hallstatt Period } \\
700-400 B C\end{array}$ & \begin{tabular}{|c} 
La Tène Period \\
$400-80 \mathrm{BC}$
\end{tabular} & $\begin{array}{l}\text { Roman Period } \\
80 B C-350 A D\end{array}$ & \begin{tabular}{|c|} 
Migration Period \\
$350-700 \mathrm{AD}$
\end{tabular} & $\begin{array}{c}\text { Early Middle } \\
\text { Ages } \\
\text { to } 966 \mathrm{AD} \\
\end{array}$ \\
\hline fortifications & :ọ:: & :ִ: & - & :⿱宀:: & : ְ⿱宀: & 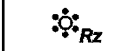 & :ִ: & 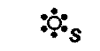 \\
\hline larger settlements & $\odot_{P M}$ & $\odot_{N}$ & $\odot_{B}$ & $\odot_{H}$ & $\odot_{L}$ & $\odot_{R z}$ & $\odot_{w L}$ & $\odot_{s}$ \\
\hline production centers & $\sim_{P M}$ & $\omega_{N}$ & $\omega_{B}$ & $\Re_{H}$ & $\omega_{L}$ & $a_{R z}$ & $\omega_{w L}$ & $\omega_{s}$ \\
\hline caves & $\Delta_{P M}$ & $\Delta_{N}$ & $\Delta_{B}$ & $\Delta_{H}$ & $\Delta_{L}$ & $\Delta_{R z}$ & $\Delta_{w L}$ & $\Delta_{s}$ \\
\hline barrows & $\Delta_{P M}$ & $\Delta_{N}$ & $\Delta_{B}$ & $\Delta_{H}$ & $\Delta_{L}$ & $\Delta_{R z}$ & $\Delta_{w L}$ & $\Delta_{s}$ \\
\hline burial grounds & $\aleph_{P M}$ & $\xi_{N}$ & $\mathfrak{w}_{B}$ & $\xi_{H}$ & $w_{L}$ & $\aleph_{R z}$ & $\xi_{w L}$ & $\sum_{s}$ \\
\hline $\begin{array}{l}\text { burial grounds with } \\
\text { stone rings }\end{array}$ & $\nabla_{P M}$ & $\nabla_{N}$ & $\mathbb{R}_{B}$ & $\sigma_{H}$ & $\nabla_{L}$ & $\mathbb{R}_{R z}$ & $\nabla_{w L}$ & $\nabla_{s}$ \\
\hline cult centers & $\vec{\Omega}_{P M}$ & $\vec{\Omega}_{N}$ & $\vec{\Omega}_{B}$ & $\widetilde{\Omega}_{H}$ & $\vec{\Omega}_{L}$ & $\vec{R}_{R z}$ & $\vec{\Omega}_{w L}$ & $\vec{n}_{s}$ \\
\hline treasures & $\sigma_{P M}$ & $\sigma_{N}$ & $\sigma_{B}$ & $\infty_{H}$ & $\sigma_{L}$ & $\sigma_{R z}$ & $\sigma_{w L}$ & $\sigma_{s}$ \\
\hline
\end{tabular}

Fig. 5. An example of a table legend created for the purpose of illustrating two features characteristic of archeological sites. 
When representing cultural landscape elements of equal significance (at the same nominal measurement level) on a map, it is important to design the symbols in such a way so that their graphic form is not suggestive of a hierarchy. To that end, one should be able to skillfully handle the variables of shape, orientation, color (to a certain extent), and graininess. The variables of size and shading should not be used, since they help in the ordering of graphic elements: (small ? large, light ? dark), what can lead to an incorrect interpretation of map content.

\section{CONCLUSION}

The questions highlighted in the article mainly follow from the author's experiences while writing Koncepcja mapy dziedzictwa przyrodniczo-kulturowego Polski 1: 50000 [An Outline of the Natural and Cultural Heritage Map of Poland 1: 50 000] (Opach, Pasławski, 2003). This is therefore a look at the problem through the prism of the practice of cartography. A person, who is the user of maps which illustrate cultural landscape, may have a different point of view regarding the issues discussed.

The map is an excellent carrier of information about cultural landscape. This stems from its nature - that it is a format allowing the spatial systematization of research results. This realization is crucial for those interested in cultural landscape.

The increasing interest in cultural landscape calls for a worked-out methodology. Maps, thematic maps in particular, are its indispensable tool. The prominent role of thematic maps in cultural landscape research encourages the further exploration of this field.

In the nearest future, research should be geared towards using Geographic Information Systems (GIS). Combining maps, tables, descriptions, photographs, films and music, they are equally ideal for researching the material and spiritual aspects of cultural landscape.

\section{REFERENCES}

Bertin J., 1970, La graphique, Communications, No 15, 169-185.

Bogdanowski J., 1976, Kompozycje i planowanie $w$ architekturze krajobrazu [Composition and Planning in Landscape Architecture; in Polish], Zakład Narodowy im. Ossolińskich, Wrocław - Warszawa - Kraków - Gdańsk.

Bogd a now ski J., 1994, Metoda jednostek $i$ wnętrz architektoniczno-krajobrazowych (JARKWAK) $w$ studiach $i$ projektowaniu [The Method of Units and Architecture-Landscape Interiors (JARK-WAK) in Studies and Design; in Polish], Politechnika Krakowska, Kraków.

Dylik J., 1948, Rozwój osadnictwa w okolicach Łodzi [Settlement Development in the Vicinity of Łodź; in Polish], Acta Geographica Universitatis Lodziensis, No 4, Łódzkie Towarzystwo Naukowe, Łódź.

Fisher A., 1933, Metoda etnograficzna w zastosowaniu do kultury społecznej i duchowej [The Ethnographic Method Applied to Societal and Spiritual Culture; in Polish], Materiaty III Konferencji Stowiańskich Etnografów i Geografów w Królestwie Jugostawii [Materials 
from the 3rd Slavic Ethnography and Geography Conference in the Kingdom of Yugoslavia; in Polish] 1930, Belgrad, 15-16.

Ławecka D., 2000, Wstep do archeologii [Introduction to Archeology; in Polish], Instytut Archeologii Uniwersytetu Warszawskiego, Warszawa.

Opach T., Pasławski J., 2003, Koncepcja mapy dziedzictwa przyrodniczo-kulturowego Polski 1:50 000 [An Outline of the Natural and Cultural Heritage Map of Poland 1:50 000; in Polish], Polski Przegl. Kartogr., Vol. 35, No 1, 3-11.

Piskozub A., 1987, Dziedzictwo polskiej przestrzeni [The Heritage of the Polish Territory; in Polish], Zakład Narodowy im. Ossolińskich, Wrocław - Warszawa - Kraków - Gdańsk - Łódź.

Ratajski L., 1989, Metodyka kartografii społeczno-gospodarczej [The Methodology of SocioEconomic Cartography; in Polish], Państwowe Przedsiębiorstwo Wydawnictw Kartograficznych, Warszawa.

Smoleński J., 1933, Morfologja granic etnograficznych w związku z ich genezą [The Morphology of Ethnographic Borders in Relation to Their Genesis; in Polish], Materiaty III Konferencji Stowiańskich Etnografów i Geografów w Królestwie Jugosławii, 1930, [Materials from the 3rd Slavic Ethnography and Geography Conference in the Kingdom of Yugoslavia], Belgrad, 21-22.

Szulc H., 1995, Morfogeneza osiedli wiejskich w Polsce [The Morphogenesis of Rural Settlements in Poland; in Polish], Prace Geograficzne, No 163, IGiPZ PAN, Warszawa.

U mińs ki T., 1994, Biologia. Podręcznik dla klasy drugiej liceum ogólnokształcacego [Biology. Coursebook for Grade 2 of Secondary School], Wydawnictwa Szkolne i Pedagogiczne, Warszawa.

Znaniecki F., 1973, Socjologia wychowania, [The Sociology of a Good Upbringing; in Polish], vol. II, Państwowe Wydawnictwo Naukowe, Warszawa.

English translation: Joanna M. Kwiatowska 